\title{
ANALISIS HARGA POKOK PRODUKSI, NILAI TAMBAH DAN KEUNTUNGAN AGROINDUSTRI KERIPIK TEMPE DI KOTA METRO
}

\author{
(Analysis of the Cost of Production, Added Value and Profit of Tempe Chips Agroindustry in Metro City)
}

Amni Apriyani, Dwi Haryono, dan Adia Nugraha

\begin{abstract}
Jurusan Agribisnis, Fakultas Pertanian, Universitas Lampung, Jl. Prof. Dr. Soemantri Brojonegoro No.1
Bandar Lampung 35141, e-mail: dwi.haryono@fp.unila.ac.id
\end{abstract}

\begin{abstract}
This research aims to analyze main production cost, added value, and income of tempe chips agroindustry. This research uses a case study method at three tempe chips agroindustries which are located in Metro City. Therefore, they are chosen purposively by considering the agroindustries are still active to produce. Respondents of this research are the owners of the tempe chips agroindustries. The field research was conducted in February until March 2019. The data collected in this research are primary and secondary data. Then, data analysis method uses quantitative descriptive analysis. The results showed that main production cost of tempe chips agroindustry is IDR32,874.39 per kilogram. Added values of tempe chips agroindustry show the positive values hence it is feasible to be developed. Tempe chips agroindustries are profitable because of the $R / C$ values of more than 1 .
\end{abstract}

Key words: added value, agroindustry, cost, income, tempe chips

\section{PENDAHULUAN}

Sektor pertanian sebagai sektor pemimpin dalam pembangunan nasional. Pembangunan pertanian harus disertai dengan pengembangan industri, baik industri hulu maupun industri hilir. Agroindustri merupakan industri pengolahan yang berbahan baku utama dari produk pertanian. Pengembangan sektor pertanian ini selanjutnya tidak hanya untuk meningkatkan jumlah produksi saja, tetapi juga meningkatkan nilai tambah, meningkatkan penyerapan tenaga kerja, serta dapat meningkatkan pendapatan produksi dari produk tersebut yaitu dengan cara melakukan usaha agroindustri. (Tambunan, 2003).

Sektor industri pengolahan memiliki kontribusi yang meningkat dari 18,64\% pada tahun 2016 menjadi 18,90\% tahun 2017 (Badan Pusat Statistik, 2017). Hal ini menunjukkan bahwa Provinsi Lampung memiliki potensi pengembangan sektor tersebut. Sektor industri pengolahan merupakan sektor penting dalam pertumbuhan Kota Metro. Kontribusi sektor tersebut terhadap PDRB meningkat dari 17,02\% tahun 2016 menjadi 17,05\% tahun 2017 (Badan Pusat Statistik Kota Metro, 2018).

Sektor industri pengolahan di Kota Metro berbasis komoditas pertanian atau biasa dikenal sebagai agroindustri, bahan baku utamanya adalah sumber daya alam pertanian yang dapat menghasilkan berbagai produk olahan, salah satu usaha agroindustri tersebut adalah usaha keripik. Usaha keripik yang paling banyak diusahakan di Kota Metro yaitu usaha keripik tempe. Kota Metro memiliki agroindustri keripik tempe sebanyak 17 agroindustri yang tersebar di setiap kecamatan, dan terbesar 42,50\% berada di Kota Metro (Dinas Koperasi, UKM dan Perindustrian Kota Metro, 2018).

Keripik tempe merupakan salah satu produk olahan hasil pertanian yang banyak di usahakan oleh masyarakat Metro, karena keripik tempe merupakan produk unggulan yang memiliki nilai ekonomi cukup tinggi serta mampu mengembangkan usaha kecil mikro dan menengah di bidang usaha pembuatan aneka keripik. Agroindustri keripik tempe merupakan industri yang potensial dan mampu bertahan di tengah persaingan dengan industri makanan yang lain.

Harga bahan baku kedelai impor cenderung naik diikuti dengan harga bahan pendukung lainnya dan upah kerja. Kondisi ini akan mempengaruhi harga pokok produksi keripik tempe. Harga pokok produksi merupakan total biaya yang dikeluarkan oleh produsen untuk memproduksi suatu produk. Perhitungan harga pokok produksi perlu dilakukan untuk mengetahui berapa biaya yang dikeluarkan oleh produsen selama melakukan kegiatan usahanya sehingga produsen mengetahui apakah 
harga yang diterima atas penjualan hasil produknya itu menguntungkan atau tidak.

Pengolahan kedelai menjadi tempe untuk meningkatkan nilai tambah pada agroindustri tersebut sehingga memperoleh nilai jual yang tinggi, kemudian untuk menjadi produk olahan yang lebih tahan lama dan siap untuk dikonsumsi maka dilakukan dengan cara pembuatan keripik tempe, dengan adanya proses pengolahan terhadap komoditas tersebut diharapkan dapat meningkatkan nilai ekonomis yang tinggi sehingga keuntungan yang diperoleh semakin besar. Berdasarkan uraian permasalahan, tujuan dari penelitian ini yaitu (1) menganalisis harga pokok produksi keripik tempe, (2) menganalisis nilai tambah keripik tempe dan (3) keuntungan yang dihasilkan oleh agroindustri keripik tempe di Kota Metro.

\section{METODE PENELITIAN}

\section{Lokasi, Sampel, dan Data}

Penelitian dilakukan di agroindustri keripik tempe di Kota Metro. Penentuan lokasi penelitian dilakukan secara sengaja purposive dengan pertimbangan bahwa daerah tersebut merupakan sentra agoindustri keripik tempe di Kota Metro. Responden dalam penelitian ini adalah pemilik agroindustri keripik tempe, sebanyak tiga agroindustri yaitu keripik tempe Bapak Syahroni, keripik tempe Bapak Tulus, dan keripik tempe Bapak Saleh dengan pertimbangan bahwa agroindustri tersebut aktif dan berproduksi secara berkontinue serta telah melakukan proses dua tahapan yaitu pengolahan kedelai menjadi tempe kemudian pengolahan tempe menjadi keripik tempe. Penelitian ini menggunakan metode studi kasus (Arikunto, 2004).

Pengumpulan data penelitian dilakukan pada Bulan Februari - Maret 2019. Data yang dikumpulkan pada penelitian ini adalah data primer dan data sekunder. Data primer diperoleh dari wawancara menggunakan kuesioner dan pengamatan langsung tentang keadaan di lapangan mengenai agroindustri keripik tempe yang digunakan dalam penelitian. Data sekunder diperoleh dari lembaga/ instansi terkait. Metode analisis data yang digunakan pada penelitian ini adalah analisis kuantitatif dan analisis deskriptif kualitatif.

\section{Metode Analisis \\ Analisis Harga Pokok Produksi (HPP)}

Tabel 1. Harga pokok produksi menggunakan full Costing

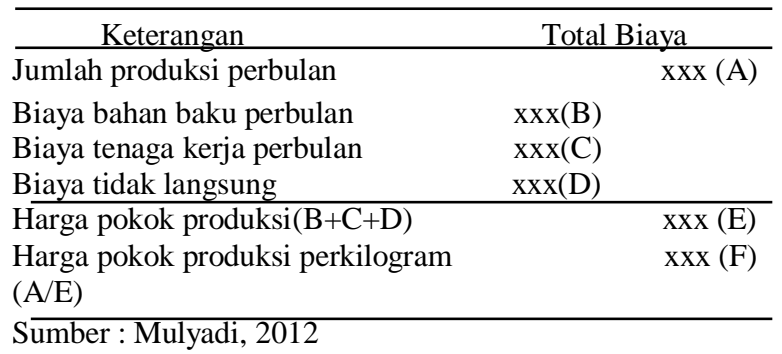

Untuk menjawab tujuan penelitian yang pertama mengenai besar harga pokok produksi usaha agroindustri keripik tempe, penentuan harga pokok produksi dalam penelitian ini menggunakan metode full costing. Metode full costing merupakan metode penentuan harga pokok produksi yang menghitung semua unsur biaya bahan baku, biaya tenaga kerja dan biaya tidak langsung baik yang bersifat variabel maupun tetap.

\section{Analisis Nilai Tambah}

Analisis nilai tambah dilakukan untuk mengetahui nilai tambah dari pengolahan kedelai menjadi keripik tempe. Perhitungan nilai tambah keripik tempe pada agroindustri keripik tempe di Kota Metro menggunakan metode Hayami (1987). Kriteria nilai tambah:

1. Jika NT $>0$, berarti pengembangan agroindustri pengolahan keripik tempe memberikan nilai tambah (positif).

2. Jika NT $<0$, berarti pengembangan agroindustri pengolahan keripik tempe memberikan nilai tambah (negatif ).

\section{Analisis Keuntungan}

Untuk menjawab tujuan penelitian yang ketiga mengenai keuntungan usaha agroindustri keripik tempe, menggunakan analisis keuntungan. Keuntungan adalah hasil selisih antara pendapatan total dengan biaya total yang dikeluarkan dalam memproduksi keripik tempe. Secara matematis dapat ditulis sebagai berikut (Rahim dan Hastuti, 2007) :

$\Pi=\mathrm{TR}-\mathrm{TC}$

Keterangan:

$\Pi=$ keuntungan usaha agroindustri keripik tempe (Rp) 
$\mathrm{TR}=$ total penerimaan/pendapatan usaha agroindustri keripik tempe (Rp)

$\mathrm{TC}=$ total biaya usaha agroindustri keripik tempe (Rp)

Penerimaan dapat dihitung dengan menggunakan rumus yaitu :

$\mathrm{TR}=\mathrm{P} \times \mathrm{Q}$

Keterangan :

$\mathrm{P}=$ Harga produk keripik tempe $(\mathrm{Rp})$

$\mathrm{Q}=$ Jumlah produk keripik tempe $(\mathrm{Kg})$

Untuk biaya total dapat dihitung dengan menghitung harga pokok produksi, dapat dilihat pada Tabel 1, kemudian dilakukan analisis R/C rasio tujuannya untuk mengetahui kelayakan usaha pada agroindustri keripik tempe dengan menggunakan indikator Revenue Cost Ratio (R/C), dimana $\mathrm{R} / \mathrm{C}$ merupakan perbandingan antara penerimaan total usaha dengan biaya total yang dikeluarkan selama proses produksi berlangsung. Nilai nisbah biaya dan penerimaan dapat diperoleh dari rumus :

$\mathrm{R} / \mathrm{C}=\mathrm{TR} / \mathrm{TC}$

Keterangan :

$\mathrm{R} / \mathrm{C}=$ nisbah penerimaan dan biaya

$\mathrm{TR}=$ Total Revenue (penerimaaan total)

$\mathrm{TC}=$ Total Cost $($ biaya total $)$

Menurut Soekartawi (2000) kriteria pegambilan keputusan adalah:

a. Jika $\mathrm{R} / \mathrm{C}>1$, maka usaha keripik tempe yang dilakukan menguntungkan, karena penerimaan lebih besar dari biaya total.

b. Jika $\mathrm{R} / \mathrm{C}<1$, maka usaha keripik tempe yang dilakukan tidak menguntungkan, karena penerimaan lebih kecil daripada biaya total.

c. Jika $\mathrm{R} / \mathrm{C}=1$, maka usaha keripik tempe yang dilakukan tidak menguntungkan dan tidak juga merugi, karena penerimaan total sama dengan biaya total.

\section{HASIL DAN PEMBAHASAN}

\section{Keadaan Umum Responden Agroindustri Keripik Tempe}

Responden pada penelitian berjumlah 3 orang yaitu pemilik agroindustri keripik tempe. Ketiga responden agroindustri keripik tempe di Kota Metro memiliki umur 42-51 tahun yang tergolong pada usia produktif sehingga cukup potensial untuk melakukan kegiatan pada agroindustri keripik tempe. Tingkat pendidikan responden sudah cukup baik karena pendidikan terakhir yaitu Sekolah Menengah Atas (SMA). Pengalaman usaha responden yaitu rata-rata selama 5-10 tahun dengan memiliki jumlah anggota keluarga yaitu 5 orang.

\section{Biaya Bahan Baku}

Biaya bahan baku yang dikeluarkan oleh pengolah kedelai menjadi tempe yaitu $\mathrm{Rp} 8.500,00 / \mathrm{kg}$ dan Rp 20.000,00/kg tempe untuk bahan baku keripik tempe. Besarnya biaya bahan baku yang dikeluarkan tergantung dari jumlah bahan baku yang digunakan, sehingga biaya yang dikeluarkan selama satu bulan sebesar Rp 5.316.666,67. Setiap agroindustri memiliki frekuensi produksi berbeda beda, pada agroindustri milik Pak Syahroni melakukan produksi dalam satu bulan sebanyak 20 kali, sedangkan Pak Tulus sebanyak 15 kali dan Pak Saleh sebanyak 24 kali dalam satu bulan. Rata - rata jumlah produksi yang dihasilkan dalam satu bulan adalah $445,00 \mathrm{~kg}$.

\section{Biaya Tidak Langsung}

Biaya tidak langsung adalah biaya yang meliputi semua biaya produksi selain biaya bahan baku dan biaya tenaga kerja. Biaya tidak langsung bersifat variabel dan tetap. Jumlah rata - rata perbulan sebesar Rp 7.698.500,00. Biaya tidak langsung yang bersifat tetap yang digunakan dalam proses pengolahan kedelai menjadi tempe yang kemudian diolah menjadi keripik tempe adalah biaya penyusutan alat - alat produksi yaitu dengan jumlah rata - rata perbulan Rp 84.314,81. Biaya tidak langsung variabel dapat dilihat pada Tabel 2. 
Tabel 2. Biaya tidak langsung variabel agroindustri keripik tempe di Kota Metro, 2019

\begin{tabular}{clr}
\hline No & Keterangan & $\begin{array}{r}\text { Jumlah rata-rata perbulan } \\
(\mathrm{Rp})\end{array}$ \\
\hline 1 & Tepung beras & $583.000,00$ \\
2 & Tepung aci & $590.000,00$ \\
3 & Garam & $118.000,00$ \\
4 & Penyedap rasa & $49.166,67$ \\
5 & Bawang putih & $188.333,33$ \\
6 & Minyak goreng & $1.740 .000,00$ \\
7 & Plastik & $1.081 .666,67$ \\
8 & Gas & $1.290 .000,00$ \\
9 & Biaya & $728.333,33$ \\
& transportasi & $300.000,00$ \\
10 & Biaya listrik & $1.030 .000,00$ \\
11 & Biaya TK tak & \\
\hline & langsung & Jumlah \\
\hline
\end{tabular}

\section{Biaya Tenaga Kerja}

Agroindustri keripik tempe di Kota Metro mempunyai tenaga kerja masing - masing agroindustri yaitu milik bapak Syahroni berjumlah 6 orang, 2 orang merupakan tenaga kerja dalam keluarga, dan 4 orang tenaga kerja luar keluarga. Tenaga kerja agroindustri keripik tempe pak Tulus berjumlah 5 orang, 2 orang dari dalam keluarga dan 3 orang berasal dari luar keluarga dan jumlah tenaga kerja agroindustri pak Saleh berjumlah 4 orang, 2 orang dalam keluarga dan 2 orangnya lagi berasal dari luar keluarga,biaya tenaga kerja untuk dalam keluarga $\mathrm{Rp} 30.000$ dan biaya luar keluarga Rp 40.000 per produksinya. Hasil penelitian menunjukan bahwa rata - rata biaya tenaga kerja langsung yaitu biaya tenaga kerja bersih pada agroindustri keripik tempe dalam satu bulan adalah Rp 1.253.333,33.

\section{Proses Pengolahan Keripik Tempe}

Berikut bagan proses pengolahan keripik tempe dapat dilihat pada Gambar 1 .

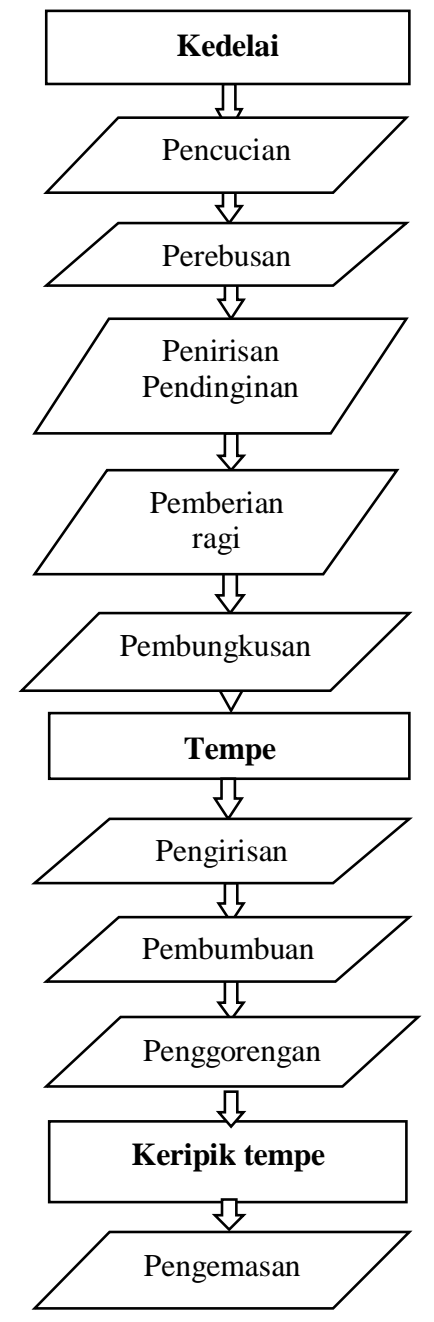

Gambar 1. Bagan proses pengolahan keripik tempe pada agroindustri keripik tempe di Kota Metro

\section{Harga Pokok Produksi Keripik Tempe}

Tabel 3. Harga pokok produksi keripik tempe dengan Metode Full Costing, 2019

\begin{tabular}{lcc}
\hline Keterangan & \multicolumn{2}{c}{ Total Biaya } \\
\hline Jumlah produksi perbulan & & $445,00(\mathrm{~A})$ \\
Biaya bahan baku perbulan & $5.316 .666,67(\mathrm{~B})$ & \\
Biaya tenaga kerja perbulan & $1.253 .333,33(\mathrm{C})$ & \\
Biaya tidak langsung & $7.698 .500,00(\mathrm{D})$ & \\
\hline Harga pokok produksi & $14.352 .814,81(\mathrm{E})$ & \\
HPP perkilogram & & $32.874,39(\mathrm{~F})$ \\
(A/E) & & \\
\hline Sumber : Mulyadi, 2012 & &
\end{tabular}

Harga pokok produksi adalah semua biaya yang telah dikorbankan dalam proses pengolahan. Perhitungan harga pokok produksi keripik tempe dapat dilihat pada Tabel 3 yang menunjukkan bahwa perolehan harga pokok produksi per kilogram dengan menggunakan metode full costing pada agroindustri keripik tempe yaitu sebesar Rp $32.874,39$. Perhitungan harga pokok produksi per kilogram ini diperoleh dengan membagi total harga 
pokok produksi yaitu sebesar Rp 14.352.814,81. Harga jual keripik tempe adalah Rp 50.000/kg lebih besar dari harga pokok produksi sehingga agroindustri keripik tempe merupakan usaha yang menguntungkan dengan harga jual yang berlaku sekarang, karena harga jual tersebut di atas dari harga pokok produksi.

Hasil perhitungan harga pokok produksi ini mendukung penelitian Hadi, Ismono dan Yanfika (2015) yang menyatakan apabila hasil perhitungan harga pokok produksi lebih kecil dibandingkan dengan harga jual standar yang sudah ditentukan oleh pengolah, maka akan memberikan keuntungan dan dapat dijadikan sebagai dasar penentuan harga jual selanjutnya.

\section{Analisis Nilai Tambah Keripik Tempe}

Perhitungan nilai tambah dalam analisis ini adalah dengan melakukan dua tahapan yaitu analisis nilai tambah pembuatan kedelai menjadi tempe dan analisis nilai tambah pembuatan tempe menjadi keripik tempe. Perhitungan nilai tambah pada penelitian ini dihitung untuk rata - rata per satu kali produksi, dengan analisis nilai tambah menggunakan metode Hayami.

Berdasarkan Tabel 4, menunjukkan bahwa nilai konversi rata - rata pada ketiga responden agroindustri keripik tempe di Kota Metro yaitu sebesar 1,33 artinya bahwa setiap 1 kilogram kedelai yang diolah akan menghasilkan $1,33 \mathrm{~kg}$ tempe.

Produksi tempe menghasilkan koefisien tenaga kerja sebesar 0,20 artinya banyaknya tenaga kerja yang digunakanuntuk mengolah tempe sebanyak 1 kilogram kedelai sebesar 0,20 HOK, dengan input tenaga kerja yang terlibat dalam pengolahan tempe per produksinya yaitu 2,00 HOK. Sumbangan bahan lain yang digunakan yaitu sebesar $\mathrm{Rp}$ $2.869,79$ yang artinya bahwa sumbangan input lain yang digunakan pada agroindustri sebesar satu kilogram bahan baku menjadi tempe yaitu $\mathrm{Rp}$ $8.503,13$.

Pada penelitian ini didapatkan hasil nilai imbalan tenaga kerja yaitu sebesar $\mathrm{Rp} 6.666,67$ artinya bahwa setiap satu kilogram bahan baku kedelai yang diolah menjadi tempe akan menghasilkan imbalan bagi tenaga kerja sebesar $\mathrm{Rp}$ 6.666,67. Imbalan tenaga kerja tersebut diperoleh dari perkalian jumlah tenaga kerja per unit bahan baku terhadap tingkat upah yang berlaku.
Tabel 4. Analisis nilai tambah Hayami pembuatan tempe agroindustri keripik tempe di Kota Metro, 2019

\begin{tabular}{lcr}
\hline Variabel & Satuan & \multicolumn{1}{c}{ Jumlah } \\
Output, input dan harga & & \\
\hline Output & $\mathrm{Kg} / \mathrm{produksi}$ & 13,33 \\
Bahan baku & $\mathrm{Kg} / \mathrm{produksi}$ & 10,00 \\
Tenaga kerja & $\mathrm{HOK} /$ produksi & 2,00 \\
Faktor konversi & $\mathrm{Kg} / \mathrm{produksi}$ & 1,33 \\
Koefisien tenaga kerja & $\mathrm{HOK} / \mathrm{kg}$ & 0,20 \\
Harga output & $\mathrm{Rp} / \mathrm{kg}$ & $20.000,00$ \\
Upah rata - rata tenaga & $\mathrm{Rp} / \mathrm{HOK}$ & $33.333,33$ \\
kerja & & \\
\hline Pendapatan,nilai tambah & & \\
\hline Harga bahan baku & $\mathrm{Rp} / \mathrm{kg}$ & $8.500,00$ \\
Sumbangan input lain & $\mathrm{Rp} / \mathrm{kg}$ & $8.503,13$ \\
Nilai output & $\mathrm{Rp} / \mathrm{kg}$ & $26.666,67$ \\
Nilai tambah & $\mathrm{Rp} / \mathrm{kg}$ & $9.663,54$ \\
Rasio nilai tambah & Persen & 35,80 \\
Imbalan tenaga kerja & $\mathrm{Rp} / \mathrm{kg}$ & $6.666,67$ \\
Bagian tenaga kerja & Persen & 73,43 \\
keuntungan & $\mathrm{Rp} / \mathrm{kg}$ & $2.996,88$ \\
Bagian keuntungan & Persen & 26,57 \\
\hline Balas jasa & & \\
\hline Margin keuntungan & $\mathrm{Rp} / \mathrm{kg}$ & $18.166,67$ \\
Keuntungan & Persen & 14,94 \\
Tenaga kerja & Persen & 37,59 \\
Input lain & Persen & 47,48 \\
\hline & &
\end{tabular}

Harga bahan baku utama yaitu sebesar Rp 8.500,00 Nilai keuntungan yang diperoleh adalah $\mathrm{Rp}$ 2.996,88 dengan bagian keuntungan sebesar 26,57 persen dari nilai output. Nilai keuntungan tersebut merupakan selisih dari nilai tambah dengan imbalan tenaga kerja. Nilai tambah yang diperoleh dari pengolahan satu kilogram kedelai menjadi tempe rata-rata sebesar Rp 9.663,54.

Setelah perhitungan nilai tambah pada tahap pertama yaitu pembuatan tempe, maka selanjutnya menganalisis perhitungan nilai tambah pada proses pembuatan keripik tempe. Analisis nilai tambah pembuatan keripik tempe pada agroindustri keripik tempe dapat dilihat pada Tabel 5, dapat diketahui nilai konversi proses analisis perhitungan nilai tambah pembuatan keripik tempe pada agroindustri keripik tempe di Kota Metro yaitu 1,68, hal tersebut berarti setiap satu kilogram tempe yang diolah akan menghasilkan rata - rata keripik tempe sebesar 1,68 kilogram. Produksi keripik tempe menghasilkan koefisien tenaga kerja sebesar 0,25 artinya banyaknya tenaga kerja yang digunakan pada agroindustri keripik tempe sebesar 0,25 HOK. Sumbangan input lain yang digunakan dalam pengolahan keripik tempe yaitu $\mathrm{Rp} 25.467,88$, artinya bahwa sumbangan input lain yang digunakan sebesar satu kilogram tempe menjadi keripik tempe yaitu $\operatorname{Rp} 25.467,88$. 
Tabel 5. Analisis nilai tambah Hayami pembuatan keripik tempe agroindustri keripik tempe di Kota Metro, 2019

\begin{tabular}{lcr}
\hline Variabel & Satuan & \multicolumn{1}{l}{ Jumlah } \\
Output, input dan harga & & \\
\hline Output & $\mathrm{Kg} /$ produksi & 22,33 \\
Bahan baku & $\mathrm{Kg} / \mathrm{produksi}$ & 13,33 \\
Tenaga kerja & $\mathrm{HOK} /$ produksi & 3,33 \\
Faktor konversi & $\mathrm{Kg} / \mathrm{produksi}$ & 1,68 \\
Koefisien tenaga kerja & $\mathrm{HOK} / \mathrm{kg}$ & 0,25 \\
Harga output & $\mathrm{Rp} / \mathrm{kg}$ & $50.000,00$ \\
Upah rata - rata tenaga & $\mathrm{Rp} / \mathrm{HOK}$ & $35.000,00$ \\
kerja & & \\
\hline Pendapatan,nilai tambah & & \\
\hline Harga bahan baku & $\mathrm{Rp} / \mathrm{kg}$ & $20.000,00$ \\
Sumbangan input lain & $\mathrm{Rp} / \mathrm{kg}$ & $25.467,88$ \\
Nilai output & $\mathrm{Rp} / \mathrm{kg}$ & $83.777,78$ \\
Nilai tambah & $\mathrm{Rp} / \mathrm{kg}$ & $38.309,90$ \\
Rasio nilai tambah & Persen & 45,74 \\
Imbalan tenaga kerja & $\mathrm{Rp} / \mathrm{kg}$ & $8.888,89$ \\
Bagian tenaga kerja & Persen & 23,60 \\
keuntungan & $\mathrm{Rp} / \mathrm{kg}$ & $29.421,01$ \\
Bagian keuntungan & Persen & 76,40 \\
\hline Balas jasa & & \\
\hline Margin keuntungan & $\mathrm{Rp} / \mathrm{kg}$ & $63.777,78$ \\
Keuntungan & Persen & 46,16 \\
Tenaga kerja & Persen & 13,93 \\
Input lain & Persen & 39,91 \\
\hline
\end{tabular}

Pada penelitian ini didapatkan nilai imbalan tenaga kerja yaitu 8.888,89, artinya bahwa setiap satu kilogram bahan baku menghaslkan imbalan tenaga kerja sebesar 8.888,89 per kilogram. Harga bahan baku Rp 20.000,00 dengan memperoleh nilai keuntungan sebesar Rp 29.421,01 dengan bagian keuntungan sebesar 76,40 persen dari nilai output.

Beradasarkan nilai keuntungan tersebut dapat diartikan bahwa 76,40 persen dari nilai tambah merupakan keuntungan bersih karena sudah memperhitungkan imbalan tenaga kerja. Nilai tambah yang diperoleh dari pengolahan satu kilogram tempe menjadi keripik tempe rata-rata sebesar Rp 38.309,90 per kilogram tempe. Rasio nilai tambah untuk pengolahan keripik tempe sebesar 45,74 persen yang berarti untuk setiap Rp 100,00 nilai produk akan diperoleh nilai tambah sebesar Rp 45,74. Hasil perhitungan pada Tabel 4 nilai balas jasa faktor produksi lebih tinggi pada tenaga kerja dibandingkan dengan keuntungan. Hal tersebut berbanding terbalik dengan hasil perhitungan pada Tabel 5 yaitu karena nilai balas jasa faktor produksi lebih tinggi pada keuntungan dibandingkan dengan tenaga kerja. Berdasarkan perhitungan nilai tambah tersebut agroindustri keripik tempe di Kota Metro termasuk dalam agroindustri padat modal. Artinya agroindustri keripik tempe tersebut lebih mengutamakan modal dibandingkan tenaga kerja dikarenakan agroindustri menilai bahwa modal merupakan faktor produksi utama dalam kelancaran produksi agroindustri, sehingga agroindustri lebih besar mengeluarkan biaya untuk modal dibandingkan penggunaan tenaga kerja dalam proses produksi. Hal ini sejalan dengan penelitian Novia, Zakaria dan Lestari (2013) tentang analisis nilai tambah dan kelayakan pengembangan agroindustri beras siger bahwa agroindustri tersebut masuk dalam agroindustri padat modal.

Hasil analisis nilai tambah pada agroindustri keripik tempe di Kota Metro menunjukkan bahwa nilai tambah yang diperoleh yaitu sebesar 47,53 lebih besar dari nol $(\mathrm{NT}>0)$ atau nilai tambah positif, yang artinya usaha agroindustri ini layak untuk dikembangkan atau dijalankan. Penelitian ini juga berbanding lurus dengan penelitian Sari, Hasyim, dan Widjaya (2017) yang masuk dalam agroindustri padat modal, karena nilai balas jasa pemilik faktor produksi lebih tinggi dari pada keuntungan dibandingkan dengan tenaga kerja. Artinya, agroindustri tersebut menggunakan modal yang besar sehingga teknologi yang digunakan modern.

\section{Analisis Keuntungan Keripik Tempe}

Keuntungan merupakan hasil selisih dari penerimaan dengan keseluruhan jumlah biaya total produksi. Penerimaan adalah hasil kali antara output yang dihasilkan pada agroindustri dengan harga output tersebut, sedangkan untuk biaya total dapat dihitung dengan menghitung harga pokok produksi menggunakan metode full costing. keuntungan yang dihitung pada agroindustri keripik tempe di Kota Metro adalah keuntungan per produksi. Hasil perhitungan keuntungan pada agroindustri Bapak Syahroni adalah sebesar Rp 301.916,67 dengan memperoleh nilai R/C 1,40 yang artinya usaha tersebut menguntungkan dan layak dijalankan karena nilai R/C yang diperoleh lebih dari satu. Agroindustri Bapak Tulus memperoleh nilai $\mathrm{R} / \mathrm{C} 1,47$, hal tersebut berarti agroindustri keripik tempe menguntungkan dan layak untuk dijalankan. Hasil keuntungan yang di dapat dalam setiap produksi adalah Rp 335.018,52, sedangkan pada agroindustri keripik tempe Bapak Saleh memperoleh keuntungan lebih besar dibandingkan agroindustri yang lain yaitu sebesar $\mathrm{Rp} 526.164,35$ setiap produksinya, dengan hasil nilai $\mathrm{R} / \mathrm{C}$ yaitu 1,73 yang berarti usaha tersebut menguntungkan. 
Tabel 6. Tingkat keuntungan agroindustri keripik tempe pada masing-masing unit usaha

\begin{tabular}{lrrr}
\hline \multicolumn{1}{c}{ Uraian } & \multicolumn{1}{c}{ Bpk Syh } & Bpk Tls & \multicolumn{1}{c}{ Bpk Slh } \\
\hline Penerimaan (Rp) & $1.050 .000,00$ & $1.050 .000,00$ & $1.250 .000,00$ \\
Biaya (Rp) & $748.083,33$ & $714.981,48$ & $723.835,65$ \\
Keuntungan (Rp) & $301.916,67$ & $335.018,52$ & $526.164,35$ \\
R/C & 1,40 & & 1,47 \\
\hline Rata-rata keuntungan (Rp) & & & $387.699,85$ \\
\hline Rata-rata R/C & & & 1,53 \\
\hline
\end{tabular}

Tabel 6 menunjukkan bahwa keuntungan rata-rata yang diperoleh pada agroindustri keripik tempe di Kota Metro yaitu sebesar Rp 387.699,85 dengan rata - rata $\mathrm{R} / \mathrm{C}$ ratio sebesar 1,53 yang berarti usaha tersebut menguntungkan dan layak untuk dijalankan karena nilai $\mathrm{R} / \mathrm{C}$ ratio yang diperoleh lebih dari satu. Hal tersebut berbanding lurus dengan penelitian Arviansyah, Widjaya dan Situmorang (2015) tentang analisis pendapatan dan sistem pemasaran susu kambing di Desa Sungai Langka Kecamatan Gedung Tataan Kabupaten Pesawaran bahwa usaha agroindustri layak untuk dikembangkan.

Hasil penelitian yang diperoleh juga sejalan dengan penelitian Rizky, Haryono dan Kasymir (2016) tentang analisis usaha dan strategi pengembangan ternak kalkun mitra alam Kabupaten Pringsewu Provinsi Lampung yang memperoleh keuntungan dalam menjalankan usahanya. Keuntungan yang dihitung pada agroindustri keripik tempe ini diperoleh dari selisih penerimaan terhadap biaya harga pokok produksi. Pada ketiga agroindustri tersebut agroindustri keripik tempe di Kota Metro yang memiliki keuntungan paling besar setiap produksinya yaitu bapak Saleh, hal tersebut dikarenakan pada agroindustri pak Saleh nilai input yang dikeluarkan hanya membutuhkan input yang sedikit, dan output yang dihasilkan lebih besar sehingga agroindustri bapak Saleh lebih menguntungkan dibandingkan agroindustri yang lain. .

\section{KESIMPULAN}

Rata-rata harga pokok produksi keripik tempe sebesar Rp 32.874,39 per kilogram, yang lebih rendah dibandingkan dengan harga jualnya $\mathrm{Rp}$ $50.000,00$ per kilogram. Rata - rata nilai tambah keripik tempe yang dihasilkan sebesar $\mathrm{Rp}$ 38.309,90 per kilogram bahan baku (tempe). Usaha agroindustri keripik tempe merupakan unit usaha yang menguntungkan dengan $\mathrm{R} / \mathrm{C}$ lebih dari satu yaitu 1,53 .

\section{DAFTAR PUSTAKA}

Arikunto. 2004. Prosedur Penelitian Suatu Pendekatan Praktek, Edisi Kelima. Rineka Cipta. Jakarta.

Arviansyah R, Widjaya S, dan Situmorang S. 2015. Analisis Pendapatan dan Sistem Pemasaran Susu Kambing di Desa Sungai Langka Kecamatan Gedung Tataan Kabupaten Pesawaran. JIIA, 3(4): 363-369. http://jurnal.fp.unila.ac.id/index.php/JIA/articl e/view/1085/990[20 April 2019]

Badan Pusat Statistik. 2017. Produk Domestik Regional Bruto Provinsi Lampung Menurut Lapangan Usaha 2016-2017. Badan Pusat Statistik. Lampung.

Badan Pusat Statistik Kota Metro. 2018. Produk Domestik Regional Bruto Kota Metro Menurut Lapangan Usaha 2016-2017. Badan Pusat Statistik Kota Metro. Metro.

Dinas Koperasi, UKM dan Perindustrian Kota Metro. 2018a. Data Persebaran Industri Pengolahan Makanan. Dinas Koperasi, UKM dan Perindustrian. Kota Metro.

Hadi AF, Ismono RH, dan Yanfika H. 2015. Analisis Harga Pokok Produksi, Laba Usaha, dan Permintaan Ayam Ras Pedaging Probiotik Di Kota Metro. JIIA, 3 (3) : 236243.https://media.neliti.com/media/publicatio ns/13348-ID-analisis-harga-pokok-produksilaba-usaha-dan-permintaan-ayam-raspedaging-probio.pdf [21 April 2019].

Hayami Y. 1987. Agricultural Marketing and Processing in Upland Java.A Perspective From a Sunda Village. CGPRT. Bogor.

Mulyadi. 2012. Akuntansi Biaya Edisi ke-5. Cetakan Kesebelas. STIM YKPN. Yogyakarta.

Novia W, Zakaria WA, dan Lestari DAH. 2013. Analisis Nilai Tambah dan Kelayakan Pengembangan Agroindustri Beras Siger di Bandar Lampung. JIIA, 1 (3) : 210-217. http://jurnal.fp.unila.ac.id/index.php/JIA/articl e/view/705/647 [19 Maret 2019].

Rahim A dan Hastuti DRW. 2007. Ekonomi Pertanian. Penebar Swadaya. Jakarta. 
Rizky A, Haryono D, dan Kasymir E. 2016. Analisis Usaha dan Strategi pengembangan Ternak Kalkun Mitra Alam Kabupaten Pringsewu Provinsi Lampung. JIIA,4 (3) : 235-242. https://media.neliti.com/media/ publications/101006-ID-analisis-usaha-danstrategi-pengembangan.pdf [17 Juni 2019].
Sari RY, Hasyim AI, dan Widjaya S. 2017. Rantai Pasok dan Nilai Tambah Keripik Nangka Pada Agroindustri Keripik Panda Alami di Kecamatan Gedong Tataan Kabupaten Pesawaran. JIIA. 6 (3): 257-262. http://jurnal.fp.unila.ac.id/index.php/JIA/articl e/view/1034. [17 Juni 2019].

Soekartawi. 2000. Pengantar Agroindustri. PT Raja Grafindo Persada. Jakarta.

Tambunan T. 2003. Perkembangan Sektor Pertanian di Indonesia, Beberapa Isu Penting. Ghalia Indonesia. Jakarta. 